\title{
SCREENING FOR NATURAL PRODUCTS OF SHOREA Spp. AND ANISOPTERA Spp. OF THE FAMILY DIPTEROCARPACEAE FROM PASIR MAYANG, JAMBI, SUMATERA
}

\author{
HILMANAFFANDI,ARIFNURYADIN,SUSILOB.PRAYOGA \\ SEAMEO B1OTROP, Jl. Raya Tajur Km. 6 \\ Bogor. Indonesia \\ and \\ ROGERW. READ \\ Department of Organic Chemistry \\ The New South Wales University, P.O. Box I \\ Kensington, N.S.W. 2033, Australia
}

\begin{abstract}
Screening of 12 species of Shorea and 2 species of Anisoptera from the forest of Pasir Mayang, Jambi with brine shrimp (Anemia salina) lethality bioassay showed that Shorea gibosa and Anisoptera marginata have sufficient activity for further investigation. Bioassay-guided fractionation of the active extract of S. gibosa led to the isolation of stigmasterol and the shoreaphenol. Bioassay-guided fractionation of the active extract of $A$. marginata resulted in the isolation of lupenone and 3-methoxy-4-hydroxybenzoic acid O-p-C glucopyranoside as the bioactive compound.
\end{abstract}

Key words: Plant natural products/Sftorea gibosalAnisoptera marginatalActive extracts/Bioassay/Pasir Mayang.

\section{INTRODUCTION}

Dipterocarp timbers are well known to resist biological attack from many sources. Shorea robusta was shown to be highly resistant to the termites Microcerotermes beesoni and Heterotermes indicola (Sen-Sarma 1963). Particle boards constructed from Shorea species are also protected against Cryptotermes cynocephalus (Moi 1980). Fresh resin of Anisoptera thurifera appears to protect beenests from termites (Messer 1984).

Dipterocarp woods cause substantial mortality to insects feeding on them. Over a three-month test period, termites feeding on Shorea species suffered up to 99\% mortality, while termites feeding on the nondipterocarp Dyera costolata showed only a 13\% death rate (Moi 1980). Chemical factors in either resins and bark may also protect dipterocarps from microbial attack. Untreated dipterocarp timbers are reported to be highly resistant to fungal invasion (Bakshi et al. 1967), and volatile components of Hopea papuana were shown to inhibit fungal growth (Messer 1984). Bacterial growth inhibitors of dipterocarp origin include essential oils of Valeria indica (Bhagarva and Chauan 1968) and stemnoporol and alpha-copalliferol from Sri Lankan dipterocarps (Sootheeswaran et al. 1983). 
The research described here attempts to identify the active compounds that are responsible for their toxicities against brine shrimp (Artemia salina). The crude extracts of the stem bark of twelve species of Shorea and two species of Anisoptera collected from Pasir Mayang, Jambi, Sumatera were screened with brine shrimp lethality bioassay. Bioassay-guided fractionation of the active extracts led to the isolation of the active substances reported in this paper.

\section{METHODOLOGY}

\section{General}

'H n.m.r spectra were recorded at $500 \mathrm{MHz}$ and ${ }^{13} \mathrm{C}$ n.m.r spectra were measured at $125.6 \mathrm{MHz}$ on a Bruker AM 500 spectrometer. Mass spectra were recorded at $70 \mathrm{eV}$ with an A.E.I. MS 12 spectrometer. All measurements were performed at the School of Chemistry, University of New South Wales, Australia.

Initial column chromatographic separations were made on Merck 60 silica gel. Merck Kieselgel 60 F254 was employed for preparative TLC with a 1 mm layer of adsorbent on 20 x $20 \mathrm{~cm}$ glass plates and $200 \mathrm{mg}$ of material applied to each plate. Analytical TLC was performed on commercial aluminium-packed Merck Kieselgel $60 \mathrm{~F}_{254}$ Art. 5554 plates, visualised under UV $254 \mathrm{~nm}$ light or by charring after applying a $4 \% \mathrm{H}_{2} \mathrm{SO}_{4} / \mathrm{MeOH}$ spray.

\section{Plant material}

The stem bark of twelve species ofShorea i.e. S. opalis, S. guiso, S. selanica, S. seminis, S. pinanga, S. stenoptera forma, S. stenoptera (Burck)., 5. mecistopteryx, S. leprosula, S. palembanica, S. multiflora, S. gibosa and two species of Anisoptera namely A. marginata, and A.costata were collected from Pasir Mayang, Jambi, Sumatera.

\section{Extraction and isolation}

An amount of $20 \mathrm{~g}$ of air dried plant materials from each species ofShorea and Anisoptera was extracted with methanol at room temperature. The crude extracts were evaporated under reduced pressure. Sea water was poured into a small tank and shrimp eggs were added to the tank provided with an aerator. After two days the shrimp eggs hatched and mature as naupili. Each crude extract was weighed (20 mg) and dissolved in dichloromethane $(2 \mathrm{ml})$. From this solution 500, 50, 5 ul were transferred to small petri dishes corresponding to 1000, 100, $10 \mathrm{ug} / \mathrm{ml}$ (ppm), respectively. The solvent was evaporated by standing at ambient temperature overnight. After two days (when shrimp larvae are ready), sea water was added to each petri dish, inoculated with 10 shrimp per dish (30 shrimp per dilution), and the 
volume was adjusted with sea water to $5 \mathrm{ml} /$ dish. The number of surviving shrimps were recorded after 24 hours. The data were analysed with a Finney computer program to determine $\mathrm{LC}_{50}$ values and 95\% confidence intervals (Hostettmann 1991). Each crude extract of the sample was tested in three replicates against a single control. The controls were treated in a similar manner without the presence of crude extracts. The results of the initial screening are compiled in Table 1.

Table 1. Relative toxicity of the crude extracts against brine shrimp at 1000, 100, and 10 ppm

\begin{tabular}{|c|l|c|}
\hline No & \multicolumn{1}{|c|}{ Species } & LC $_{50}(\mathrm{nQ} / \mathrm{ml}$ (c.i. 95\%)* \\
\hline 1 & LShorea opalis & 513 \\
\hline 2 & Anisoptera marginata & 293 \\
\hline 3 & S. guiso & 1114 \\
\hline 4 & S. selanica & 270 \\
\hline 5 & S. seminis & 392.4 \\
\hline 6 & S. pinanga & 717 \\
\hline 7 & S.stenoptera forma & 691 \\
\hline 8 & S. mec/sfopterix & 394.9 \\
\hline 9 & S. leprosula & 259 \\
\hline 10 & S. stenopfera Burck. & $-\mathrm{ve}$ \\
\hline 11 & Anisoptera costafa & $-\mathrm{ve}$ \\
\hline 12 & S. palembanica & 882 \\
\hline 13 & S. multiflora & 346 \\
\hline 14 & S. gibosa & 205 \\
\hline
\end{tabular}

c.i. $95 \%=$ confidence intervals $95 \%$

-ve = not toxic at a concentration of more than 1000 ppm

The result of the screening indicated that the crude extracts of Shorea gibosa, $S$ leprosula, and S. selanica with toxicity level $\left(\mathrm{LC}_{50}\right)$ at 205, 259, and 270, respectively, showed significant activity against brine shrimp. Meanwhile among Anisoptera spp., A.marginata showed sufficient toxicity $\left(\mathrm{LC}_{50}=293\right)$. In this preliminary work, however only S. gibosa and A. marginata were chosen for further investigation. Therefore, large-scale extraction and fractionation of both species were carried out in the next phase of the research.

Extraction and fractionation of Shorea gibosa. The air-dried plant material of $S$. gibosa was extracted with methanol. The crude extracts (100.2 g) were extracted with hexane to remove the hexane-soluble fraction (19.8 g), and the residues were chromatographed by column chromatography (silica gel 60). The initial solvent system used in the column was hexane. The polarity of the solvent was gradually increased by the addition of chloroform into the solvent system until the mixture of hexane and chloroform became $60 \%$ in hexane. The solvent system was then changed, initially by adding $5 \%$ of methanol into the chloroform until the con- 
centration of methanol became $30 \%$ in chloroform. The fractions were grouped and monitored by analytical thin layer chromatography (TLC) to obtain 14 fractions. All fractions, including the hexane fraction, were screened with the brine shrimp lethality bioassay (Table 2).

Table 2. Relative toxicity of the fractions against brine shrimp

\begin{tabular}{|l|c|}
\hline \multicolumn{1}{|c|}{ Fractions } & LCso (ng/ml) (c.i.95\%) \\
\hline Fraction 1 & -ve \\
Fraction 2 & -ve \\
Fraction 3 & 823 \\
Fraction 4 & \\
Fraction 5 & 882 \\
Fraction 6 & 226 \\
Fraction 7 & \\
Fraction 8 & 240 \\
Fraction 9 & 132 \\
Fraction 10 & \\
Fraction 1 1 & 127 \\
Fraction 12 & Fraction 13 \\
Fraction 14 & \multicolumn{2}{|c|}{ c.i. 95\% confidence intervals 95\% } \\
-ve = not resistant at a concentration of more than
\end{tabular}

The results showed fraction 9 to be the most toxic fraction, followed by fraction 14, 10, 8, and 7. However, due to time limitation and budgetary constraints only fraction 9 was subjected to further investigation. Therefore, fraction $9(1.15 \mathrm{~g})$ was purified by preparative TLC, eluted initially with hexane, and later with the mixture of hexane and chloroform ( $3: 7)$ to yield three fractions.

Fraction 1 (0.46 g) consisted of a mixture of 4 - 5 compounds as shown by analytical TLC.

Fraction 2 (0.31 g) was dissolved in a mixture of chloroform and methanol. The mixture was allowed to stand overnight and precipitation occurred. The precipitation was filtered to give solid material as a white amorphous crystal of stigmasterol $(0.13 \mathrm{~g})$, m.p. $169^{\circ} \mathrm{C}$.

Meanwhile solid material present in fraction $3(0.22 \mathrm{~g})$ was filtered and recrystallised with chloroform-methanol, afforded shoreaphenol as orange crystalline compounds ( $13.27 \mathrm{mg}$; m.p. $240^{\circ} \mathrm{C}$ ).

Extraction and fractionation of Anisoptera marginata. Air-dried stem bark of A. marginata $(1.7 \mathrm{~kg})$ were extracted with methanol. After removing the solvent under reduced pressure the crude extract (121.4 g) was extracted with hexane, to remove the hexane-soluble fraction $(19.02 \mathrm{~g})$. The remaining crude extract (102.38 g) was subjected to column chromatography (silica gel 60), initially eluted with 
chloroform, and later with methanol by increasing the polarity at 30\%, 60\%, 80\% and $100 \%$ levels. The fractions were pulled and monitored by analytical TLC to yield 18 fractions. Fraction 1 to 10 were combined, since the components of those fractions were relatively similar judging from analytical TLC. All fractions, including the hexane fraction, were screened with the brine shrimp lethality bioassay (Table 3 ).

Table 3. Relative toxicity of the fractions against brine shrimp

\begin{tabular}{|l|c|}
\hline \multicolumn{1}{|c|}{ Fractions } & LCjo (ng/ml) (c.i.95\%) \\
\hline Hexane fraction & -ve \\
Fraction 1 1 & 300 \\
Fraction 12 & 114 \\
Fraction 13 & 65 \\
Fraction 14 & 44 \\
Fraction 15 & \\
Fraction 16 & \\
Fraction 17 & \\
\hline
\end{tabular}

The results indicated that fraction 14 was most toxic. Fraction 14 (1.43 g) was subjected to preparative TLC, eluted twice initially with hexane followed by $30 \%$ chloroform in hexane, to yield fraction 1 (0.87 g), fraction $2(0.13 \mathrm{~g})$, fraction 3 (0.03 g); and fraction 4 (0.49 g).

Solid material present in fraction 1 was filtered, followed by recrystalisation in chloroform to yield the triterpenoid lupenone as a white crystalline amorf $(0.21 \mathrm{~g})$, m.p $160^{\circ}$. Fraction 4 was dissolved in methanol and a crystalline solid was produced upon addition of a few drops of methanol. The solid residue was filtered and recrystallised with a mixture of chloroform and methanol to yield a colorless crystal (0.16 g), m.p. $145^{\circ}$. All fractions, including two compounds isolated from fraction 1 and 2, were tested with the brine shrimp lethality bioassay (Table 4).

Table 4. Relative toxicity of the fractions against brine shrimp

\begin{tabular}{|l|l|}
\hline \multicolumn{1}{|c|}{ Fractions } & \multicolumn{1}{|c|}{$\mathrm{LC}_{\mathrm{W}}$ (tig/ml) (c.i. 95\%) } \\
\hline $\begin{array}{l}\text { Lupenone Fraction 2 } \\
\text { Fraction 3 glue. } \\
\text { comp. }\end{array}$ & -ve-ve-ve \\
& \\
\hline
\end{tabular}

c.i $95 \%$ = confidence intervals 95\%

-ve $=$ not toxic at a concentration of more than $1000 \mathrm{ppm}$ 


\section{RESULTS AND DISCUSSION}

Methanolic extract of the stem bark of $S$. gibosa, followed by fractionation by column chromatography and monitored by TLC resulted in 14 fractions. The fractions were screened with brine shrimp lethality bioassay and purification of the active fractions led to the isolation of non-biologically active compound stigmasterol. The structure of stigmasterol was established by ${ }^{~} \mathrm{H}$ and ${ }^{\mathrm{I}} \mathrm{C}$ n.m.r. spectroscopy (Fig. 1). The 'H n.m.r. spectrum showed two methyl singlets, 80.57 , 1.01; three methyl doublets, 8 0.79, 0.84, 1.03; and a methyl triplet, 8 0.80. Also three proton multiplets corresponding to two internally coupled, trans olefinic protons 85.03 (dd, J 15.1, $8.4 \mathrm{~Hz}$, and 5.15 (dd, J 15.1, $8.4 \mathrm{~Hz}$ ) and an isolated olefinic proton $(85.18, \mathrm{~m})$ with long range coupling were present, but no other signals occurred at higher chemical shift than $2.5 \mathrm{ppm}$. The presence of a 1,2disubstituted and a 1,1,2-trisubstituted olefin was supported by the presence of signals at $8117.0(\mathrm{CH}), 129.6(\mathrm{CH}), 138.1(\mathrm{CH})$ and $139.5(\mathrm{C})$ in the "C n.m.r.
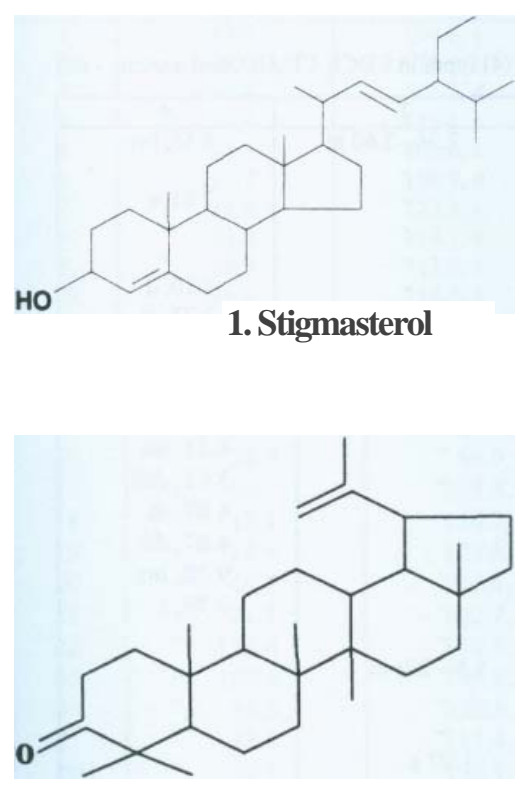

3. Lupenone
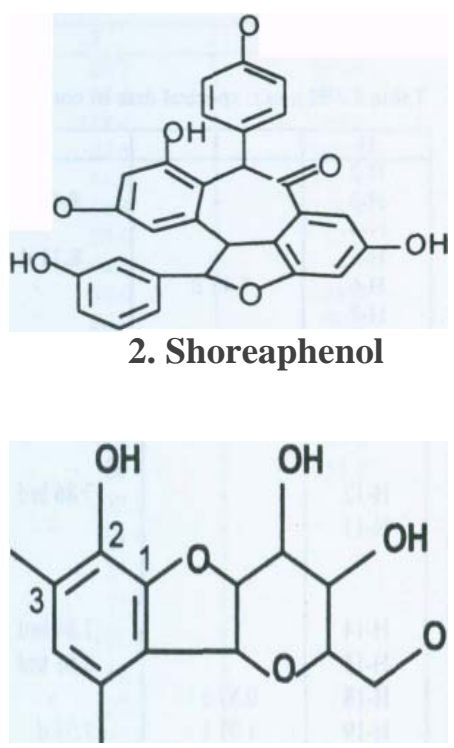

4. 3-methoxy-4-hydroxybenzoic acid-O-p-C glucopyranoside

Figure 1. Structure of chemical constituents isolated from the bark of Shorea gibosa (1 and 2) and Anisoptera marginata (3 and 4). 
spectrum. The presence of a quaternary signal at 8212.0 also confirmed the occurrence of a carbonyl group in the compound. The structure of stigmasterol was also confirmed by mass spectrometry at $m l z 367\left(\mathrm{M}^{-} \mathrm{C}_{3} \mathrm{H}_{7}\right), 298\left(\mathrm{M}-\mathrm{C}_{8} \mathrm{H}{ }_{6}\right), 271(\mathrm{M}-$ $\mathrm{C}, 0 \mathrm{H}, 9), 269\left(\mathrm{M}-\mathrm{C}_{10} \mathrm{H}_{2}\right)$, and comparative melting point analysis. Stigmasterol is widely distributed in the plant kingdom. Application of this compound as therapeutic agents is very limited, although extensive exploratory activities in this area have been underway during recent years (Mahato'ef a/. 1992).

The solid material produced from fraction 4 of the active fraction was filtered, followed by repeated crystallisation to give an orange crystalline solid of shoreaphenol. The ' $\mathrm{H}$ n.m.r. spectroscopy (Table 5) data revealed the presence of signals at $68.61(2 \mathrm{H}$, br d, J 8.7Hz, H-ll and H-15), $7.84(2 \mathrm{H}$, br d, J 8,7Hz, H12 and $\mathrm{H}-14$ ), 7.74 (2H, br d, J 8.8Hz, H-24 and H-28), and 7.44 (2H, br d, J 8.8Hz, $\mathrm{H}-25$ and $\mathrm{H}-27)$. These signals clearly indicated the presence of two pdisubstituted benzene nuclei. The 'H n.m.r. spectrum also established signals for four m-coupled proton at $68.42(1 \mathrm{H}, \mathrm{d}, \mathrm{J} 2.1 \mathrm{~Hz}, \mathrm{H}-3), 8.11(1 \mathrm{H}, \mathrm{d}, \mathrm{J} 2.1 \mathrm{~Hz}, \mathrm{H}-$ 5), $7.58(1 \mathrm{H}, \mathrm{d}, \mathrm{J} 2.5 \mathrm{~Hz}, \mathrm{H}-19)$ dan $7.33(1 \mathrm{H}, \mathrm{d}, \mathrm{J} 2.5 \mathrm{~Hz}, \mathrm{H}-21)$. In addition to these signals, five

Table 5. 'H n.m.r. spectral data of compounds (1) - (4) (ppm in $\mathrm{CDCl}_{3}, \mathrm{CD}_{3} \mathrm{OD}$, and acetone - d6)

\begin{tabular}{|c|c|c|c|c|}
\hline H & 1 & 2 & 3 & 4 \\
\hline $\mathrm{H}-2$ & - & - & $2.36-2.60 \mathrm{~m}$ & $8.56, \mathrm{brs}$ \\
\hline $\mathrm{H}-3$ & - & $8.42 \mathrm{~d}$ & . & - \\
\hline $\mathrm{H}-4$ & - & - & - & $7.01, \mathrm{~s}$ \\
\hline H-5 & 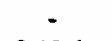 & $8.11 \mathrm{~d}$ & - & - \\
\hline $\mathrm{H}-6$ & $5.45 \mathrm{~d}$ & - & - & $\therefore$ \\
\hline $\mathrm{H}-7$ & - & - & - & $5.10, \mathrm{~d}$ \\
\hline H-9 & - & - & - & $3.77, \mathrm{~m}$ \\
\hline $\mathrm{H}-10$ & - & - & - & $\begin{array}{l}3.44, \mathrm{dt} \\
5.43, \mathrm{~d}\end{array}$ \\
\hline $\mathrm{H}-11$ & - & $8.61 \mathrm{brd}$ & - & $\begin{array}{l}3.84, \mathrm{~m} \\
5.62, \mathrm{~d}\end{array}$ \\
\hline $\mathrm{H}-12$ & - & $7.86 \mathrm{brd}$ & - & $4.11, \mathrm{dd}$ \\
\hline $\mathrm{H}-13$ & - & - & - & $\begin{array}{l}3.62, \mathrm{ddt} \\
4.07, \mathrm{~m} \\
4.87, \mathrm{dd}\end{array}$ \\
\hline $\mathrm{H}-14$ & - & $7.84 \mathrm{brd}$ & - & 9.30 , brs \\
\hline H-15 & - & $8.61 \mathrm{brd}$ & - & $3.79, \mathrm{~s}$ \\
\hline H-18 & $0.57 \mathrm{~s}$ & - & - & - \\
\hline H-19 & $1.01 \mathrm{t}$ & $7.58 \mathrm{~d}$ & $1.5-2.0 \mathrm{~m}$ & - \\
\hline $\mathrm{H}-21$ & - & $7.33 \mathrm{~d}$ & - & - \\
\hline H-22 & $5.15 \mathrm{dd}$ & - & - & - \\
\hline H-23 & $5.03 \mathrm{dd}$ & - & $1.07 \mathrm{~s}$ & - \\
\hline $\mathrm{H}-24$ & - & $7.74 \mathrm{brd}$ & $1.19 \mathrm{~s}$ & - \\
\hline H-25 & - & 7.44 brd & $0.94 \mathrm{~s}$ & - \\
\hline H-26 & $0.79 \mathrm{~d}$ & - & $0.97 \mathrm{~s}$ & - \\
\hline H-27 & $0.84 \mathrm{~d}$ & $7.43 \mathrm{brd}$ & $0.89 \mathrm{~s}$ & - \\
\hline H-28 & - & $7.76 \mathrm{brd}$ & - & - \\
\hline H-29 & $0.80 \mathrm{t}$ & - & $4.57 \mathrm{dd}, 4.70 \mathrm{~d}$ & - \\
\hline
\end{tabular}


phenolic hydroxyl protons were also discernible in the 'H n.m.r. spectrum in the region 7.92 to 7.96 .

The ${ }^{13} \mathrm{C}$ n.m.r. spectra (Table 6) were characteristic of substituted a and (3carbons of the benzofuran nucleus. Furthermore, the appearance of one proton at 5.98 (8c 54.97, d) clearly suggested the presence of-CH-CO- in the molecule of shoreaphenol. The mass spectrometry data are consistent with the assigned structure $m / z$ 466. Comparison of the ' $\mathrm{H}$ and ${ }^{13} \mathrm{C}$ n.m.r. spectral data and its melting point of shoreaphenol with those reported (Saraswathy et al. 1992) suggested close similarity.

The methanolic extract of the bark of the tree of Anisoptera marginata was fractionated by column chromatography using silica gel, and monitored with TLC to give 9 fractions. Brine shrimp bioassay of those fractions showed the fraction eluted with chloroform-methanol $(8: 2)$ to be the most active fraction. The active fraction was subjected by preparative TLC, and the precipitation that occurred in fraction 1

Table 6. ${ }^{13} \mathrm{C}$ n.m.r. chemical shift data of compounds (1) - (4) (ppm in $\mathrm{CDCl}_{3}, \mathrm{CD}_{3} \mathrm{OD}$, and acetone -d6)

\begin{tabular}{|c|c|c|c|c|}
\hline C & 1 & 2 & 3 & 4 \\
\hline 1 & 37.3 & $199.8, \mathrm{~s}$ & 39.7 & 150.9 \\
\hline 2 & 29.7 & $123.4, \mathrm{~s}$ & 34.1 & 148.3 \\
\hline 3 & 140.8 & $111.2, \mathrm{~d}$ & 218.4 & 139.9 \\
\hline 4 & 71.9 & $155.1, \mathrm{~s}$ & 47.3 & 109.0 \\
\hline 5 & 42.3 & $103.6, \mathrm{~s}$ & 54.9 & 115.7 \\
\hline 6 & 121.7 & $156.9, \mathrm{~d}$ & 19.6 & 118.7 \\
\hline 7 & 31.4 & $122.1, \mathrm{~s}$ & 33.0 & 72.3 \\
\hline 8 & 31.9 & $114.1, \mathrm{~s}$ & 40.3 & - \\
\hline 9 & 50.3 & $153.6, \mathrm{~s}$ & 50.6 & 81.6 \\
\hline 10 & 36.6 & $116.5, \mathrm{~s}$ & 36.9 & 70.5 \\
\hline 11 & 21.1 & $127.8, d$ & 21.9 & 74.1 \\
\hline 12 & 39.8 & $115.7, \mathrm{~d}$ & 26.7 & 79.6 \\
\hline 13 & 42.4 & $158.3, \mathrm{~s}$ & 39.5 & 61.3 \\
\hline 14 & 56.9 & $116.4, \mathrm{~d}$ & 41.0 & 163.1 \\
\hline 15 & 24.4 & $129.0, \mathrm{~d}$ & 26.4 & 59.6 \\
\hline 16 & 28.9 & $56.0, d$ & 30.1 & \\
\hline 17 & 56.1 & $129.8, \mathrm{~s}$ & 44.9 & \\
\hline 18 & 12.1 & $130.2, \mathrm{~s}$ & 37.7 & \\
\hline 19 & 19.4 & $108.8, \mathrm{~d}$ & 52.5 & \\
\hline 20 & 40.5 & $154.4, \mathrm{~s}$ & 150.8 & \\
\hline 21 & 21.3 & $102.7, \mathrm{~d}$ & 30.3 & \\
\hline 22 & 138.3 & $155.3, \mathrm{~s}$ & 23.2 & \\
\hline 23 & 129.4 & $135.2, \mathrm{~s}$ & 26.8 & \\
\hline 24 & 51.3 & $130.6, \mathrm{~d}$ & 20.9 & \\
\hline 25 & 32.0 & $115.4, \mathrm{~d}$ & 16.3 & \\
\hline 26 & 19.1 & $158.9, \mathrm{~s}$ & 15.4 & \\
\hline 27 & 21.1 & $114.8, \mathrm{~d}$ & 14.2 & \\
\hline 28 & 25.4 & $130.3, \mathrm{~d}$ & 151.1 & \\
\hline 29 & 12.3 & & 101.8 & \\
\hline 30 & & & 20.7 & \\
\hline
\end{tabular}


was filtered and crystallised with chloroform to yield the terpenoid lupenone as a white crystalline amorf $(0.21 \mathrm{~g})$, m.p $160^{\circ}$. The structure of lupenone was established from ' $\mathrm{H}$ and ${ }^{13} \mathrm{C}$ n.m.r. (Table 5 and 6). The 'H n.m.r. spectral data indicated the presence of five singlet resonances at $80.89,0.94,0.97,1.07$ and 1.19, arising from six methyl groups attached to quaternary carbons. There also appeared one isolated singlet at 81.68 due to a vinylogous methyl group, and the olefmic proton signals at 84.56 (dd, J 2.2, $1.4 \mathrm{~Hz}$ ) and 4.68 (d, J $2.2 \mathrm{~Hz}$ ) were consistent with a 1,1-disubstituted alkene, a propenyl group was likely. Low field signals resonance at 83.18 (dd, J 10, 9, $5.3 \mathrm{~Hz}$ ), 2.38 (dt, J 5.7, $11.1 \mathrm{~Hz}$ ) and $1.91(\mathrm{~m})$ occurred, but there were no other olefinic resonances. The n.m.r. signal at 83.18 was suggestive of an axial proton adjacent to a quaternary centre and attached to a carbon bearing hydroxyl group. The ${ }^{13} \mathrm{C}$ n.m.r. spectrum (Table 5) supported the structural assignment of lupenone. In particular there appeared seven methyl signals, only two olefinic carbon signals $8109.3\left(\mathrm{CH}_{2}\right)$ and $151.0(\mathrm{C})$, and a low field methine resonance ( 8 78.9) for C3. The identity of compound (1) as lupenone was confirmed by melting point and mixed melting point with an authentic sample (Affandi et al. 1998).

The solid material produced in fraction 4 was filtered, followed by recrystallisation in methanol to give 3-methoxy-4-hydroxybenzoic acid O-p-C glucopyranoside as a colorless crystalline amorf ( 0.98 g), m.p $145^{\circ}$. The ' $\mathrm{H}$ and ${ }^{13} \mathrm{C}$ n.m.r spectral data of 3-methoxy-4-hydroxybenzoic acid-O-p-C-glucopyranoside are shown in Table 5 and 6.

The Infrared (IR) spectrum of the compound disclosed the broad absorption at $3600-2500 \mathrm{~cm}^{\prime \prime}$ and the carbonyl stretch at $1700 \mathrm{~cm}^{\prime 1}$. This is in agreement with the compound being an acid. The 'H n.m.r. spectrum of the compound- showed the signals of the following protons (acetone-d6, $500 \mathrm{MHz}$ ): proton in 3-methoxy-4hydroxybenzoic acid, $83.79(3 \mathrm{H}, \mathrm{s}), 7.01(1 \mathrm{H}, \mathrm{s}), 8.56(1 \mathrm{H}$, br s), $9.30(1 \mathrm{H}, \mathrm{br} \mathrm{s})$. Proton in a glucopyranoside ring, $84.11(1 \mathrm{H}, \mathrm{dd}), 3.77(1 \mathrm{H}, \mathrm{m}), 3.44(1 \mathrm{H}, \mathrm{dt})$, $3.84(1 \mathrm{H}, \mathrm{m}), 3.62$ and 4.07 (each $1 \mathrm{H}$, ddt), proton in a hydrogen - bonded hydroxyl group, $84.87\left(1 \mathrm{H}\right.$, dd), $5.43(1 \mathrm{H}, \mathrm{d}), 5.62(1 \mathrm{H}, \mathrm{d})$. The ${ }^{13} \mathrm{C}$ n.m.r, spectrum of the assigned structure indicated the presence of six quaternary carbon signals at 8 109.0, 115.7, 118.7, 139.9, 148.3, 150.9. Primary carbon signals were obtained at 8 70.5, 72.3, 74.1, 79.6, 81.6, and 109.0. Signals for a carbon methoxy group at 8 59.6, carbon methylene at 861.3 and carbon acid at 8 163.1 also were obtained. Mass spectroscopy confirmed m/z 328 of the molecular formula $\mathrm{C}_{14} \mathrm{H}_{16} \mathrm{O}_{4}$. Furthermore, the location of the C-glucoside ring was confirmed by the two dimensional NOE spectroscopy (NOESY) spectrum as described in Figure 2. The long-range $\mathrm{C}-\mathrm{H}$ correlation spectra with proton detection (HMBC) as described in Figure 3 permits any coupling between $\mathrm{OH}$ protons and the carbons to which they are attached, to be detected by the appearance of cross peaks.

Brine shrimp lethality bioassay of this compound showed to be highly toxic against brine shrimp ( $\mathrm{LC}_{50}=7$ ), it means that the compound caused the mortality of 


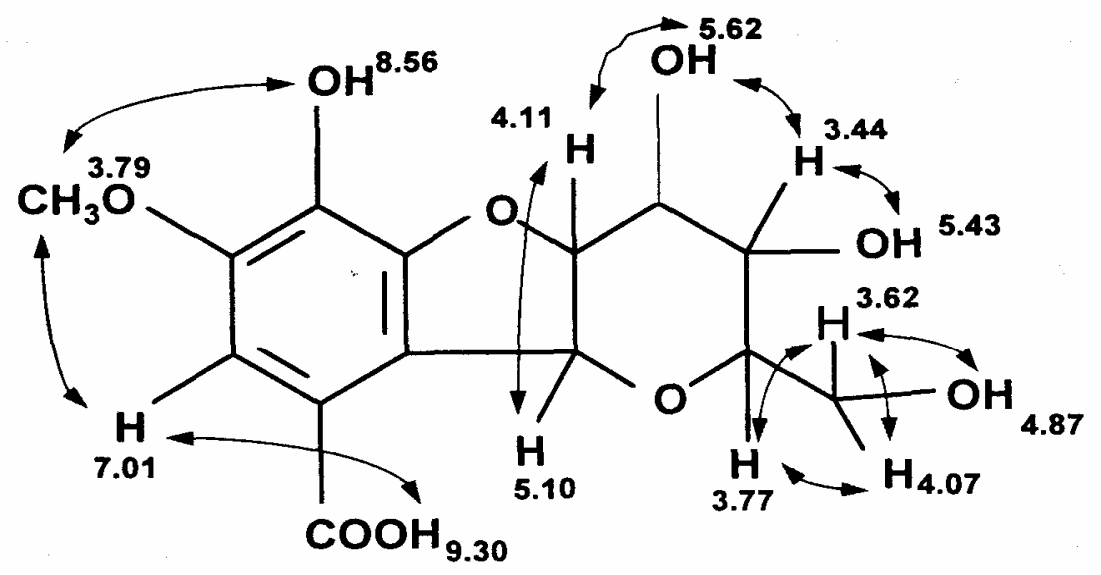

Figure 2. Two dimensional NOE spectroscopy (NOESY) of assigned structure



Figure 3. Two dimentional ${ }^{13} \mathrm{C}-{ }^{1} \mathrm{H}$ correlation spectroscopy (COLOC) of 3-methoxy-4hydroxybenzoic acid- $0-\beta-c$ glucopyranoside 
brine shrimp more than $50 \%$ at concentration 7 ppm (jig/ml). Future investigations might reveal medicinal or other uses of the compound.

\section{REFERENCES}

AFFANDI, H., A, NURYADIN, and R.W., READ 1998. Studies on Natural Products of Albizia sp., B1OTROPIA, 11, 1 -8.

BHARGARVCA, A.K., and C.S., CHAUAN. 1968. Antibacterial activity of some essential oils., Indian J. Pharm. 30:151-152.

BAKSHI, B.K., Y.N., PURI, and S., SINGH. 1967. Natural decay resistance of Indian timbers. I. Introduction and method. II. Resistance of sal (Shorea robusta Gaertn.) and teak (Tectona grandifloris L.f), Indian For., 93 : 305-328.

HOSTETTMAN, K., ED., 1991. Method in Plant Biochemistry, Vol. 6: Assays for Bioactivity, Pergamon Press, New York.

MAHATO, S.B., A.K., NANDY, and G., ROY.1992. Triterpenoids, Phytochemistry, 31(7), 2199-2249.

MESSER, A.C., 1984. Chalicodoma pluto : The world's largest bee rediscovered living communally in termite nests (Hymenoptera: Megachilidae), J. Kans. Entomol, Soc., 57 : 165-168.

Moi, L.C., 1980. A new laboratory method for testing the resistance of particle boards to the drywood termite Cryptotermes cynocephalus. Malaysian For., 43:350-355.

SARASWATHY, A., K.K., PURUSHOTHAMAN, A., PATRA, A.K., DEY, and A.B., KUNDU. 1992.

Shoreaphenol, A Polyphenol from Shorea robusta. Phytochemistry, 31(7), 2561-2562. SEN-SARMA,

P.K.. 1963. Studies on the natural resistance of timbers to termites, I. Observations on the longevity of the test termite Heterotermes indicola Wasm. in the saw dust from forty common Indian timbers. Indian For. Bull. (N.S.) Entomol, 220 : 1-3.

SOOTHEESWARAN, S., M.V.S., SULTANBAWA, S., SURENDRAKUMAR, and P., BLANDON. 1983. Polyphenols from a dipterocarp species: Copalliferol and stemnoporol. I. Chem. Soc. Perkin Trans. I, 699-702. 